\title{
Regulation of Hybrid Networks at the Intersection between Governmental Administration and Economic Self-Organisation ${ }^{\dagger}$
}

ANDREAS ABEGG*

\section{IRRITATIONS IN LAW: CO-OPERATION BETWEEN GOVERNMENT ADMINISTRATION AND PRIVATE PERSONS IN NETWORK FORM}

\section{I.1 The Case: Swiss Federal Court Decision 109 Ib 146 (1983)}

Today's increasingly co-operative relations between the state and private persons have brought numerous new problems to the law. It may even be held that the new types of 'co-operationism' between the state and private persons has plunged the law into deep crisis. This is because by freeing the administration from the constraints which are binding by statute, on the one hand, and transferring to private entities competences hitherto incumbent on government for the upholding of public interests, on the other, the basic pillars of democracy under rule of law are called into question. This can be illustrated very clearly by the example of decision 109 Ib 146 (1983) of the Swiss Federal Court on the Agreement on the Swiss banks' code of conduct with regard to the exercise of due diligence (abbreviated as 'CDB'). But this is not all: decision $109 \mathrm{Ib} 146$ also indicates that the problem of co-operationism may be closely connected with another [p.

\footnotetext{
† Translated by Iain L Fraser. Published in G Teubner/M Amstutz, Contractual Networks: Legal Issues of Multilateral Cooperation, 2009. The numbers added in brackets [] refer to the pages of the print version.

* Dr. iur., LL.M., attorney-at-law, Zürich/Switzerland, abegg@ besbes.ch
} 
256] new sort of phenomenon which is increasingly irritating the law: the organisational form of the network. ${ }^{1}$

Specifically, the object of the Federal Court decision 109 Ib 146 (1983) was that the Swiss National Bank, a public institution of the Confederation, had, without a specific legislative mandate, renewed, in the form of bilateral agreements, the 'Agreement on the Swiss banks' code of conduct with regard to the exercise of due diligence' with the overwhelming majority of Swiss banks. ${ }^{2}$ The renewed CDB of 1983 contained tighter rules on the disclosure of the identity of third parties on whose behalf assets had been invested. In contrast with earlier agreements of 1977, in this version of the CDB, the range of those not required to disclose the origin of monies to be invested was reduced. The Association of Trustees (Treuhänder-Verband), affected by this, asked to be exempted from the identity disclosure, as the lawyers and the Chamber of Trustees and Auditors (Treuhand- und Revisionskammer) had been. ${ }^{3}$ This was rejected by the National Bank in a letter to the petitioner. The Association of Trustees challenged this letter as an administrative decision in an administrative-court complaint to the Federal Court. ${ }^{4}$

Before briefly summarising the Federal Court's deliberations, let us mention the pre-history of the CDB. In the mid ' 70 s, using guarantees and sureties from a major Swiss bank, and in infringement of Swiss capital influx regulations, foreign investors had transferred money amounting to over CHF 2 billion to the Texon finance company in Vaduz (Liechtenstein), which was operative in Switzerland. ${ }^{5}$ The money invested was

\footnotetext{
${ }^{1}$ According to G Teubner, 'Coincidentia Oppositorum: Hybrid Networks beyond Contract and Organisation' (ch 1), in this volume, a network, or combination of contracts, exists where, first, the bilateral contracts reciprocally refer to each other in the performance programme or in contractual practice; secondly, there is reference in the content to the overall project; and thirdly, there is legally relevant close co-operation between the parties to the combination ('economic unit').

${ }^{2}$ For the first time in the Agreement of 9 December 1977. The Swiss Federal Court decision 109 Ib 146 was about the CDB of 1 July 1982. See the comparison of the first two versions of the CDB in P Nobel, 'Die neuen Standesregeln zur Sorgfaltspflicht der Banken' (1987) 39 Wirtschaft und Recht 149-66, with further references.

${ }^{3}$ In particular, the Treuhänder-Verband might have wanted to counter damage to its image. However, the overwhelming majority of the banks actually participated in the CDB, so that the limited choice of bank did amount to an economic disadvantage for the members of the Treuhänder-Verband.

${ }^{4}$ Federal Court decision $109 \mathrm{Ib} 146$ at 146 et seq.

${ }^{5}$ For a summary of the events, see the reports in the Neue Zürcher Zeitung (NZZ) 26 April 1977, p 15 and 28 April 1977, p 13; in detail, from the banks' perspective, see J Jung, From Schweizerische Kreditanstalt to Credit Suisse Corp-The History of a Bank (Zürich, NZZ Verlag, 2000) 245 et seq, especially at 257.
} 
linked, above all, with tax evasion and money laundering, whereupon, among other things, foreign policy pressed the Swiss legislature to take corrective action. ${ }^{6}$ The resulting scandal—which initially [p. 257] affected the political world, but affected the business world almost immediately afterwards - had so much impact on the image of the Swiss banking sector that, as a direct consequence, the self-restraint of the 'know-yourcustomer' rule was adopted, in the form of the CDB agreement in the sector. The first CDB in 1977 specifically required, in Article 4, the determination of the origins of funds. ${ }^{7}$ Once the Texon scandal had died down, the banks agreed, in 1982, upon a new version of the $\mathrm{CDB}$ with the National Bank, which, while still directed against the furtherance of economic criminality by the banking industry, ${ }^{8}$ largely formalised the duties of clarification. ${ }^{9}$

How, then, did the Federal Court, in decision $109 \mathrm{Ib}$ 146, respond to CDB 1982 as an agreement between the National Bank and the banks, and in particular to the thirdparty interests of the Treuhänder-Verband? The Federal Court did not hear the complaint, on the grounds that the CDB was a private contract, and, accordingly, the National

See Federal Court decision $105 \mathrm{Ib} 348$. Specifically, there was infringement of capital-movement regulations aimed at reducing the inflow of foreign money, particularly through levies.

${ }^{6}$ At first, mainly Italy was affected by this capital drain of approximately CHFr 2 billion: see NZZ 20 April 1977, p 15, 26 April 1977, p 15, 28 April 1977, p 13 and 6 May 1977, p 17; see also Federal Court decision $105 \mathrm{Ib} 348$, especially, facts A., E. 10d) and 11; see G Müller, 'Zur Rechtsnatur der Vereinbarung über die Sorgfaltspflichten der Banken bei der Entgegennahme von Geldern und über die Handhabung des Bankgeheimnisses' (1984) SJZ 349 at 350, Nobel, 'Die neuen Standesregeln zur Sorgfaltspflicht der Banken' (n 2 above) 149 et seq; P Nobel, Schweizerisches Finanzmarktrecht (Bern, Stämpfli, 2004) §6 N 6 , fn 6.

${ }^{7}$ The main purpose of the first CDB from 1977 has remained almost unchanged to this day: 'All due diligence which can be reasonably expected under the circumstances must be exercised in establishing the identity of the beneficial owner. If there is any doubt as to whether the contracting partner is himself the beneficial owner, the bank shall require by means of Form A a written declaration setting forth the identity of the beneficial owner'. Art 3 Abs 1 CDB 2003. For an overview of the CDB's origins, see U Zulauf, 'Gläubigerschutz und Vertrauensschutz: Zur Sorgfaltspflicht der Bank im öffentlichen Recht der Schweiz' (1994) 113 ZSR 359 at 434 et seq, D Zuberbühler, 'Das Verhältnis zwischen der Bankenaufsicht, insbesondere der Überwachung der einwandfreien Geschäftstätigkeit, und der neuen Sorgfaltspflichtvereinbarung der Banken' (1987) 39 Wirtschaft und Recht 167, and Nobel, 'Die neuen Standesregeln zur Sorgfaltspflicht der Banken' (n 2 above). As to new developments, see W de Capitani, 'Die Aufsichtskommission VSB und das zehnte Gebot' in HCvd Crone, P Forstmoser, RH Weber and R Zäch (ed), Aktuelle Fragen des Bank- und Finanzmarktrechts: Festschrift für Dieter Zobl zum 60. Geburtstag (Zürich, Schulthess, 2004).

${ }^{8}$ Explicitly stated in the preamble to CDB 1982.

${ }^{9}$ Articles 2-5 CDB 1982; see the comparison with CDB 1977 in Nobel, 'Die neuen Standesregeln zur Sorgfaltspflicht der Banken' (n 2 above). 
Bank's note to the Treuhänder-Verband was not an administrative (public law) decision that could be challenged. This is because the CDB was primarily aimed at taking over provisions from foreign penal law, in order to avert conflicts with foreign legal systems. However, since the actions targeted in the CDB - such as active assistance with tax offences or currency offences abroad-were not punishable in Swiss law, the interests theory did not lead to an allocation to public law. ${ }^{10}$ And in the subordination theory, it would seem that, while the National Bank had been 'encouraged' to act by the Swiss Federal Council (ie, the Swiss Government), it was not exercising any specific legislative mandate, and the individual banks had accordingly been at liberty either to adhere to the Agreement or not. The fact that a similar arrangement could also have been created by statute [p. 258] was not relevant in the eyes of the court. Accordingly, the CDB was to be defined as a private contract. ${ }^{11}$ At most, a complaint to a supervisory authority might be brought against the National Bank, which

in its private-law activities analogously [sic] has to comply with the constitutional basic rights. In particular, even as a subject of private law it must not confer rights or impose duties legally unequally or arbitrarily. ${ }^{12}$

Legal scholars are to date in disagreement as to the law's needful adaptations to the emerging trends to co-operationism and privatisation (or 'essentialisation' (Verwesentlichung) of the state's functions ${ }^{13}$ ): on the one hand, there are calls for the extension of public law, ${ }^{14}$ though this certainly brings the danger of stifling the new-style co-operationist forms under restrictive regulations. ${ }^{15}$ On the other, there are suggestions that the law should follow social changes by shifting corresponding situations from

\footnotetext{
${ }^{10} 109 \mathrm{Ib} 146$ (1983) 149 et seq, especially E. 2.

11109 Ib 146 (1983) 152 et seq, E. 3.

12109 Ib 146 (1983) 155, E. 4.

13 Thus, for example, G Müller, 'Wege zu einem schlanken Staat: Überprüfung der Aufgaben stete Pflicht der Staatsleitung', NZZ, 16 March 2005; for a wider perspective see also B Dörr, P Donges, M Künzler, A Ledergerber, M Puppis, E Schade and M Vogel, Selbstregulierung und Selbstorganisation, 'Unveröffentlichter Schlussbericht zuhanden des Bundesamtes für Kommunikation', available at: http://www.mediapolicy.unizh.ch/forschung/selbstregulierung_report.pdf (last visited 8 December 2006).

14 Thus, for example, Richli, who criticises the Federal Court decision $109 \mathrm{Ib} 146$ for calling the CDB a private contract, but praises it for the observation that the National Bank does come under the fundamental rights: P Richli, 'Die verwaltungsrechtliche Rechtsprechung des BGer 1983: Bankengesetz' (1985) 81 ZBJV 428-30; see, recently, also Y Hangartner, 'Bemerkungen zu BGE 129 III 35' (2003) 6 Aktuelle Juristische Praxis (AJP) 690-93.

${ }^{15}$ In 129 III 35 (2003), the Federal Court responded logically to the essentialisation of state tasks being pursued politically; see M Amstutz, A Abegg and V Karavas, Soziales Vertragsrecht (Basel, 2006).
} 
public to private law and especially the law of contract, ${ }^{16}$ which would, however, thus be confronted with standards hitherto located in public law, and thus be irritated in the extreme, to the point of calling its own premises into question. ${ }^{17}$

This extremely demanding adaptation of law to increasing governmental cooperationism is however-as is evident from decision $109 \mathrm{Ib} 146$ - at the same time, exposed to further irritations from equally far-reaching and novel changes in the environment: ie, the shifts from [p. 259] market-related organisational structures on the one hand, and hierarchical ones on the other (reflected in law as contract and corporations) to network-type structures, for which the law is not prepared with categories of its own. ${ }^{18}$

These two new-style contextual conditions of co-operationism and network structures do not always appear as isolated contextual constraints on law, but may be so interlinked as to heighten the demands on the law's adaptability. Hitherto, such phenomena have been studied under the heading of 'self-regulation under governmental direction', ${ }^{19}$ though this places insufficient emphasis on, first, the active role of the economy and secondly, the new-style network organisation. ${ }^{20}$ It seems manifest to me that co-operationism between the state and private persons happening purely in individual contracts in the foreground-yet nonetheless in the background in network structures

\footnotetext{
${ }^{16}$ Thus, for example, A Marti, 'Aufgabenteilung zwischen Staat und Privaten auf dem Gebiet der Rechtsetzung_Ende des staatlichen Rechtsetzungsmonopols?' (2002) 10 Aktuelle Juristische Praxis (AJP) 1154 at 1158 .

${ }^{17}$ For instance, in Federal Court decision 129 III 35 (2003) constitutional tasks for law of contract emerge openly: Amstutz, Abegg and Karavas, Soziales Vertragsrecht (n 15 above). And, in the theory of mutually absorbing systems, private law functionalized by public interests henceforth appears - to put it rather bluntly - as now just an appendage to public law.

${ }^{18}$ For much more on this, see G Teubner, Netzwerk als Vertragsverbund: Virtuelle Unternehmen, Franchising, Just-in-time in sozialwissenschaftlicher und juristischer Sicht (Baden-Baden, Nomos, 2004).

${ }^{19}$ Among many, Marti, 'Aufgabenteilung zwischen Staat und Privaten auf dem Gebiet der Rechtsetzung' (n 16 above), with further references; on the history of self-regulation in Switzerland, see A Mach, G Schnyder, T David and M Lüpold, 'Transformations de l'autoregulation et (re)regulation publique en matiere de gouvernement d'entreprise en Suisse (1980-2002)' (2006) 12 Revue suisse de science politique 1-32; Y Sancey, Un capitalisme de Gentlemen. Emergence et consolidation de l'autorégulation bancaire en Suisse et en Angelterre (1914-1960) (Diss) (Lausanne, unpublished thesis University of Lausanne 2004); H Bänzinger, Die Entwicklung der Bankenaufsicht in der Schweiz seit dem 19. Jahrhundert (Bern, Haupt, 1986).

${ }^{20}$ Typical of this approach is U di Fabio, 'Verwaltung und Verwaltungsrecht zwischen gesellschaftlicher Selbstregulierung und staatlicher Steuerung' in Kontrolle der auswärtigen Gewalt: Veröffentlichungen der Vereinigung der deutschen Staatsrechtslehrer Heft 56 (Berlin, Walter de Gruyter, 1997).
} 
which ultimately bring about more than the sum of the individual contracts-possesses enormously explosive implications for current legal concepts such as the rule of law binding of administrations, on the one hand, or the privity of contracts, on the other.

\section{I.2 Exploratory Movements in the Co-evolution of Politics, Economy and Law}

Once the Federal Court had assigned the CDB to private law-while at the same time pointing out the National Bank's 'analogous' binding by fundamental rights - and after the ensuing criticisms by legal scholars had highlighted the inability of the Federal Court's chosen option to provide stability and had called for the CDB to be brought back under [p. 260] public law, ${ }^{21}$ economic and political actors responded. For the new version of the CDB in 1987, the National Bank withdrew from the Agreement, thus responding to the critics who had complained of the lack of a statutory basis for the National Bank's involvement in the $\mathrm{CDB} .{ }^{22}$ This change was intended to avert the danger that the CDB might, as some critics were demanding, still be brought under public law or-even more undesirably - lead to far-reaching legislation. ${ }^{23}$ The place of the National Bank was taken by the Swiss Federal Banking Commission (Federal Banking Commission), which possessed the appropriate statutory powers as a supervisory authority to act in relation to the CDB, and, indeed, had even felt called upon to abrogate parts of the CDB in $1991 .^{24}$ Moreover, unlike the National Bank, the Federal Banking Commission no longer appeared as a direct contracting party with the banks, something similarly intended to

\footnotetext{
${ }^{21}$ See, especially, Müller, 'Zur Rechtsnatur der Vereinbarung über die Sorgfaltspflichten der Banken bei der Entgegennahme von Geldern und über die Handhabung des Bankgeheimnisses' (n 6 above); R Rhinow, 'Verfügung, Verwaltungsvertrag und privatrechtlicher Vertrag' in Juristische Fakultät der Universität Basel (ed), Privatrecht-Öffentliches Recht-Strafrecht: Grenzen und Grenzüberschreitungen; Festgabe zum Schweizerischen Juristentag (1985); R Rhinow, 'Verwaltungsrechtlicher oder privatrechtlicher Vertrag: Fiskalwirkung der Grundrechte' (1985) 4 Recht 57-64.

${ }^{22}$ Initially, the National Bank became involved because the Texon scandal not only affected the stock quotation of the Kreditanstalt, the bank involved in the scandal, but also resulted in a sharp decline of the Swiss Franc: NZZ 27 April 1977, p 17 and 5 May 1977, p 29.

${ }^{23}$ Thus also the interpretation by Zuberbühler, 'Das Verhältnis zwischen der Bankenaufsicht, insbesondere der Überwachung der einwandfreien Geschäftstätigkeit, und der neuen Sorgfaltspflichtvereinbarung der Banken' (n 7 above) 167.

${ }^{24}$ Specifically, this concerned the ban on Form B by the EBK circular of 25 April/1 July 1991: Jahresbericht der EBK zum Jahr 1991 at 17 et seq Form B allowed trustees to declare that the party actually entitled was known, but was not being disclosed.
} 
avert further politicisation. Correspondingly, the network came to meet the demands from legal scholars to equip the $\mathrm{CDB}$ with comprehensive framework legislation on the one hand, and replace it with more or less traditional professional etiquette on the other. The position at the centre of the network, concluding the individual agreements with the banks, was now taken over by the banks' private trade association, the Swiss Bankers' Association, while the Federal Banking Commission was intended to act as supervisory authority. $^{25}$

However, these changes could not prevent further pressure on Switzerland as a banking centre and on the CDB. ${ }^{26}$ Attacks on Swiss banks [p. 261] ensued during the US 'war on drugs', and this contributed to the introduction of the penal prohibition of money laundering. ${ }^{27}$ This penal provision stated, by way of a framework Act, that the identification duty was to be carried out with the care that was appropriate to the circumstances, something — so ran the message from the Swiss Federal Council ${ }^{28}$ - that was fleshed out in the CDB. Numerous legal scholars immediately accused this penal framework law of infringing the principle of clarity and definiteness. ${ }^{29}$ Renewed pressure on banking regulation, leading inter alia to further tightening of the provisions against

\footnotetext{
${ }^{25}$ As also in CDB 2008 of 7 April 2008, available at: http://www.swissbanking.org/20080410-vsb-cwe.pdf (last visited 6 October 2008). The EBK issues instructions as to which institutions a declaration on actual entitlement must be secured from (Art 3, N 34.4), receives notices of infringements from the audit office and the CDB supervisory commission (Arts 10 and 12(9)) and authorises amendments to the CDB (Art $14(3))$.

${ }^{26}$ From an evolutionary-theory viewpoint, these further developments can be brought together under the concept of punctuated equilibrium: variations do not appear in a system uniformly and gradually, but are generated above all by unexpected or even scandalous events that cause the possibility of actual evolutionary jumps (in the sense of contingency), thus differing from either arbitrariness or predetermination. See N Luhmann, Das Recht der Gesellschaft (Frankfurt aM, Suhrkamp, 1993) 243; MT Fögen, 'Rechtsgeschichte — Geschichte der Evolution eines sozialen Systems' (2002) $1 R G$ Rechtsgeschichte 14-19; M Amstutz, 'Die Verfassung von Vertragsverbindungen' in M Amstutz (ed), Die vernetzte Wirtschaft (Zürich, Schulthess, 2004) 55 et seq; Fögen has coined the appropriate expression 'sensational stories' for the jumps, and calls Gould's punctuated equilibrium an 'attractive third way the social sciences might also take': MT Fögen, Römische Rechtsgeschichten-über Ursprung und Evolution eines sozialen Systems (Göttingen, Vandenhoeck \& Ruprecht, 2002) 16 and 18 et seq; Luhmann points out that, in modern society, the punctuational aspect is radicalised by the mass media, which preferentially report divergent variations: N Luhmann, Die Gesellschaft der Gesellschaft (Frankfurt aM, Suhrkamp, 1997) 474.

${ }^{27}$ Art 305ter StGB, introduced by No I of the BG of 23 March 1990, in force since 1 August 1990 (official collection of Swiss law 19901077 1078; BBl 1989 II 1061).

${ }^{28}$ BBl 1989 I $1089 \mathrm{f}$.

${ }^{29}$ Among many: W de Capitani, 'Zum Identifikationsverfahren bei Kontoeröffnungen aus dem Ausland' (1993) 89 SJZ 21 at 21 et seq, fn 2, with further references.
} 
money laundering, came after 1992, first in connection with the Italian 'Mani pulite' campaign following bribery scandals, and more recently under the heading of terrorism. ${ }^{30}$

How did the Federal Court respond to these developments, ie, to the criticisms of decision $109 \mathrm{Ib} 146$ by the legal scholars and to the moves for modifications from politics and business? Two years after decision $109 \mathrm{Ib}$ 146, the Federal Court again had a chance to speak on the CDB. Though the case was quite different, the Federal Court considered decision $109 \mathrm{Ib}$ 146. However, it held that it would not need to examine whether the CDB was private-law or public-law in nature; and in any case, it bound the Federal Banking Commission neither to interpret the Banking Act, nor to its tasks as a supervisory body. ${ }^{31}$ Thus, the Federal Court had not only reduced the importance of the CDB as selfregulation, but also indicated in an obiter dictum that the description of the CDB as a private contract was no longer certain. In its decision 125 IV 139 (1999), the Federal Court once again reduced the importance of the CDB and the banking sector [p. 262] deregulation that it constituted. For the interpretation of the penal provision of Article 305ter $S t G B$ (money laundering), the CDB was, it said, merely an aid to interpretation. ${ }^{32}$

This is the stage, in the intersections between the discourses of economics, politics, law and scholarship, at which the CDB network finds itself today, although it continues to be disputed whether the CDB is to be classed under private or public law. ${ }^{33}$

\footnotetext{
${ }^{30}$ See, eg, Art 305ter (2), introduced by the $B G$ of 18 March 1994, in force since 1 August 1994 (official collection of Swiss law 19941614 1618; BBl 1993 III 277), and the Swiss Federal Council's message of 17 June 1996 on money laundering: BBl 1996 III 1101. On the fight against terrorism, see Art 1 of CDB 2003.

${ }^{31}$ Federal Court decision $111 \mathrm{Ib}$ 127, 127et seq.

${ }^{32}$ Federal Court decision 125 IV 139, E. 3d, 144 et seq: 'While as regards the demands on verification of identity the message refers to the model role of the $\mathrm{CDB}$, and the duties of care on financial intermediaries now introduced in the Money-laundering Act are in the words of the message meant to form the criterion for the care to be observed in financial transactions in accordance with Art 305ter Abs 1 StGB, this can of course not mean that the degree of care when receiving assets required by the penal provision is as it were absorbed into the relevant rules of the CDB. The CDB has to do with rules of professional etiquette, formulated by the Swiss Bankers' Association, to which the signatory banks submit. They are an instrument of ethical self-regulation, and serve primarily to uphold the reputation of the profession (Article $1 \mathrm{CDB}$ ) and thereby the interests of the banks, but are also protective as being self-protection against unclear situations that might lead to claims for damages. That they further lay claim to fleshing out 'the concept of the care required by the circumstances when receiving assets (Article 305ter $S t G B$ ) is not binding on the criminal-court judge - for all one's recognition for self-regulatory efforts'.

${ }^{33}$ In favour of the classification under private law, most recently, Marti, 'Aufgabenteilung zwischen Staat und Privaten auf dem Gebiet der Rechtsetzung' (n 16 above) 1158 et seq, and A Marti, 'Selbstregulierung anstelle staatlicher Gesetzgebung?' (2000) 101 ZBL 561 at 576. For allocation to public law, see, recently, U Häfelin and G Müller, Allgemeines Verwaltungsrecht (Zürich, Schulthess, 2002) fn 1060. Allocation to
} 
Centrally, the newest version, CDB 2003, is structured as follows: the Swiss Bankers' Association concludes the agreement with the signatory banks for a period of five years in each case. ${ }^{34}$ The governmental Federal Banking Commission checks whether the arrangement meets the requirements of the Money-laundering Act (Geldwäschereigesetz, $G w G) .{ }^{35}$ The CDB sees itself as a piece of regulated professional etiquette which-in order, in accordance with Article 1, 'to uphold the reputation of the Swiss banking industry at home and abroad' - fleshes out the statutorily-regulated duties of care in the Money-laundering Act and the Criminal Code, while "normal banking business ... [ought] not to be hampered thereby'. For the duties of care [p. 263] where there is a heightened risk of money-laundering, the CDB refers to national law, namely, the Federal Banking Commission regulation. ${ }^{36}$ Articles 2-9 CDB regulate the specific duties of care and define their scope. With Article 10, the signatory banks authorise a review body to monitor compliance with the $\mathrm{CDB}$, and notify the $\mathrm{CDB}$ supervisory commission and the governmental Federal Banking Commission of infringements. The supervisory commission, set up to investigate breaches, informs the Federal Banking Commission of its decisions (Article 12, especially 12(9)). Finally, an arbitration tribunal will, upon a complaint brought by the Swiss Bankers' Association against the bank concerned, hand down a final decision as to whether there has or has not been a violation of the terms of the agreement (Article 13).

private law while maintaining the bindingness of fundamental rights is advocated by M Schefer, 'Grundrechtliche Schutzpflichten und die Auslagerung staatlicher Aufgaben' (2002) 10 Aktuelle Juristische Praxis (AJP) 1131 at 1139 et seq.

${ }^{34}$ The most recent dating from 7 April 2008: see $\mathrm{n} 25$ above.

${ }^{35}$ See, especially, Arts 16 and $42 G w G$; see also J-B Zufferey and Expertengruppe Finanzmarktaufsicht, Finanzmarktregulierung und -aufsicht in der Schweiz. Schlussbericht (Bern, 2000) N 251, and Eidgenössische Finanzverwaltung, Geldwäschereibekämpfung in der Schweiz (Bern, 2003) 43, Arbeitsgruppe KYC, Sorgfaltspflichten von Banken und Effektenhändlern bei Geldwäscherei, Terrorismusfinanzierung und Beziehungen zu politisch exponierten Personen, 2005, available at: http://www.ebk.admin.ch/d/archiv/2002/pdf/neu090702-02d.pdf (last visited 8 December 2006) 12, and the explanations by the Bankers' Association at http://www.swissbanking.org/home/allgemein.htm (last visited 8 December 2006). On all this, see also Nobel, Schweizerisches Finanzmarktrecht (n 6 above) $\S 6 \mathrm{~N} 10$, §9 $\mathrm{N} 40$ et seq, especially N 55 et seq and $\S 11 \mathrm{~N} 27$.

${ }^{36}$ Art 1(3) CDB 2003; Regulation of the Confederal Banking Commission on the Prevention of MoneyLaundering of 18 December 2002. 
This concludes my reconstruction of the evolution of the CDB and of the social systems affected by the CDB. ${ }^{37}$ This reconstruction of developments to date, since the emergence of the CDB in 1977, has shown the following: the Federal Court's decision

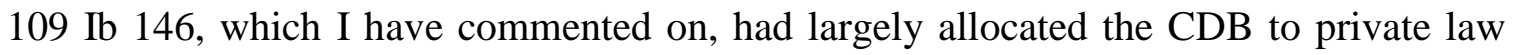
and thus given full leeway to its experimental programme. It initially sparked off vehement criticism from legal scholars, who stressed the lack of internal legal consistency in the Federal Court's ruling, especially with the concept of the democratic state under rule of law, thus showing that the decision could not bring stability. The immediately ensuing exploratory moves by the CDB network chiefly served the goal of keeping the network in the sphere of private law and thus free from political instrumentalisation, albeit without wishing to lose its link with politics. ${ }^{38}$ However, because of repeated scandals and larger political events, ${ }^{39}$ as well as the criticisms of the conflict with rule-of-law principles by legal scholars, this could not be maintained. Instead, the academic critique, on the one hand, and the scandals and broader events, on the other, engendered politically-led legislative impulses that reduced the CDB's importance as self-regulation, and increasingly subjected it to political structures. Even today, the economic, political and legal systems have yet to find lasting stability in their co-evolution in the area of the $\mathrm{CDB}$, something which is reflected in the continuing criticisms of the doctrinal classification of the CDB as private law by legal scholars. ${ }^{40}$

[p. 264] I shall cast an eye below over the law's neighbouring disciplines, in order to sound out the conditions for some possibilities of overcoming the crisis. ${ }^{41}$ At the centre is the thesis that, while legal science had identified the new-style co-operationism between the state and private persons as the starting point for the continuing irritationswhich are at the point of intersection of a clash of discourses of Babylonian

\footnotetext{
${ }^{37}$ For the dogmatic presentation of the CDB, see the relevant literature, eg, Nobel, Schweizerisches Finanzmarktrecht (n 6 above) $\S 6$, with exhaustive literature references.

${ }^{38} \mathrm{We}$ shall return to the link between the economy and politics in the network: III.2.

${ }^{39}$ Note 27 above.

${ }^{40}$ According to di Fabio, this finding is valid for the whole topic of self-regulation: di Fabio, 'Verwaltung und Verwaltungsrecht zwischen gesellschaftlicher Selbstregulierung und staatlicher Steuerung' (n 20 above) 275 .

${ }^{41}$ On the call to bring the neighbour sciences into jurisprudence, see P Gauch, 'Die Fehlerwelt der Juristen' in Festschrift für Heinz Rey (Zürich, Schulthess, 2003) fn 19 et seq.
} 
proportions - it was unable to respond properly to these new-style irritations with the old rigid concepts, which also ignored the emergence of network-type organisations bound up with co-operationism. Consequently, it needs a theory which is able to deal with the dynamic co-evolution of the various discourses involved. I shall employ evolutionary theory for this, and, in the process, attempt to make the natural-science concept of morphogenesis bear fruit.

\section{THE MORPHOGENESIS OF HYBRID NETWORKS}

According to Kämper and Schmidt, the point with networks is not the harmonisation of functional systems, still less the integration of society. ${ }^{42} \mathrm{My}$ analysis of the coevolutionary search-moves around the CDB network to date, however, points in precisely the opposite direction: the CDB network - and very generally, hybrid networks located between the social sub-systems of society-may constitute strategies of these social subsystems in order to retain their own specific system nature and respond as far as necessary to contradictory irritations simultaneously. ${ }^{43}$ What is involved here is nothing less than the social integrative function of evolution. ${ }^{44}$ However, some elucidation is called for, as follows.

[p. 265] It has more than once been pointed out that hybrid networks are an institutional reaction to ambivalent, contradictory or paradoxical requirements. ${ }^{45}$ Institutionally, this response means redundancy, ie, the system reacts to particular events

\footnotetext{
${ }^{42}$ E Kämper and JFK Schmidt, 'Netzwerke als strukturelle Kopplung' in J Weyer (ed), Soziale Netzwerke: Konzepte und Methoden der sozialwissenschaftlichen Netzwerkforschung (Munich, Oldenbourg, 2000) 227; with a different view, D Messner, 'Netzwerktheorien: Die Suche nach Ursachen und Auswegen aus der Krise staatlicher Steuerungspolitik' in E Altvater, A Brunnengräber, M Haake and H Walk (eds), Vernetzt und verstrickt: Nicht-Regierung-Organisationen als gesellschaftliche Produktivkraft (Münster, Westfälisches Dampfboot, 1997) 42 et seq.

${ }^{43}$ M Amstutz, Evolutorisches Wirtschaftsrecht: Vorstudien zum Recht und seiner Methode in den Diskurskollisionen der Marktgesellschaft (Baden-Baden, Nomos, 2001) 290 et seq; M Amstutz, 'Widerstreitende Götter-Zu Manfred Aschkes Rekonstruktion der systemsoziologischen Evolutiontheorie und ihrer rechtstheoretischen Bedeutung' (2003) 2 Rechtsgeschichte 14-24; Teubner (nn 18 and 29.

${ }^{44}$ On this, see Amstutz, Abegg and Karavas, Soziales Vertragsrecht (n 15 above).

${ }^{45}$ G Teubner, 'Das Recht hybrider Netzwerke' (2001) 165 Zeitschrift für das gesamte Handelsrecht und Wirtschaftsrecht 550-75; K-H Ladeur, Das Umweltrecht der Wissensgesellschaft: von der Gefahrenabwehr zum Risikomanagement (Berlin, Duncker \& Humblot, 1995) 31 et seq.
} 
by repeatedly reducing the possible modes of behaviour. ${ }^{46}$ Since the heightened demands from the environment cannot be escaped, the system at this point comes closer to the complexity of the environment. ${ }^{47}$ This process in which the system lowers its internal consistency in one sub-area may, borrowing from the natural sciences, be called morphogenesis. ${ }^{48}$ In fact, the CDB network is responding simultaneously-as will immediately be described in more detail — to at least three paradoxical demands from the environment, which result from the repeated banking scandals and the calls (admittedly uncomfortable for the economic system) to restrain economic logic. First, though, I wish to go into the concept of morphogenesis as further developed by the natural sciences in recent years, so as to use it as a metaphor (ie an outline solution that provides inspiration) in order to describe the function of hybrid networks in the evolution of social systems. ${ }^{49}$

Recent natural-science theories of morphogenesis fit almost precisely with Kauffman's concept of spontaneous order, exploited by Amstutz for legal theory. As SA Kauffman showed, not only does a system's evolution come from the selection of suitable variations, but the selection must also meet with an internal so-called spontaneous order, which is what makes the evolution of a system possible at all. ${ }^{50}$ This spontaneous order keeps the system in a condition in which it is best prepared for evolutionary processes. Kauffman has shown that systems are able to respond to irritations from outside when their epistatic connectivity ${ }^{51}$ is $K=2$. A [p. 266] crystal with $\mathrm{K}=1$ is, in contrast, unreceptive to external irritations, while with a higher connectivity of $\mathrm{K}=\mathrm{N}-1$, the system drifts into chaos at practically the slightest touch. Put more

\footnotetext{
${ }^{46}$ Luhmann, Das Recht der Gesellschaft (n 26 above) 355 et seq.

${ }^{47}$ Amstutz, Evolutorisches Wirtschaftsrecht (n 43 above) 291; see also Kämper and Schmid, 'Netzwerke als strukturelle Kopplung' (n 42 above) 229 et seq.

${ }^{48}$ For the natural sciences, see AV Spirov, 'Game of Morphogenesis: What Can We Learn from the Pattern-Form Interplay Models?’ (1998) 8 International Journal of Bifurcations and Chaos 991-1001, with further references, and infra n 54 et seq. For the social sciences, see Teubner (n 45, and N Luhmann, Soziale Systeme: Grundriss einer allgemeinen Theorie (Frankfurt aM, Suhrkamp, 1987) 480 et seq, and 485 et seq, with further references on adoption of the concept in the social sciences.

${ }^{49}$ On the concept of metaphor, see Amstutz, Evolutorisches Wirtschaftsrecht (n 43 above) 160 et seq.

${ }^{50}$ SA Kauffman, The origins of order: self-organisation and selection in evolution (New York, Oxford University Press, 1993); SA Kauffman, Investigations (Oxford, Oxford University Press, 2000).

${ }^{51}$ In biology, epistatic connectivity denotes dependence between genes, i.e., that one gene 'covers up' the effects of another. If, then, variant $a$ leads to phenotype A and variant $b$ to phenotype $\mathrm{B}$, but the combination $a b$ results only in phenotype $\mathrm{A}$, then $a$ is epistatic to $b$.
} 
simply, the elements of the system must be bound loosely enough to be able to take on the irritations 'at the edge of chaos', but not too loose for the system to be unable to maintain itself as such despite the irritations. ${ }^{52}$ The place, or 'unit of selection', where evolution first becomes possible along with the maintenance of intrinsic rationality is not the system in its entirety - which would be unable to effect the necessary adaptation. Instead, the system differentiates particular areas that have to accomplish this adaptation, and which are, to this end, coupled with the corresponding environment. ${ }^{53}$

This concept of spontaneous order has now been taken up by recent theories of morphogenesis: according to Harrison, morphogenesis means the emergence of a complex system from a simpler one, a process that presupposes internal spontaneous order. ${ }^{54} \mathrm{~A}$ central place in the process of morphogenesis is taken up by the interactions between the dynamic elements of the system: on the one hand, changes in the system's relationship to its environment must be grasped quickly and precisely, and communicated within the system; on the other, change should be set in motion in the system in the other direction. ${ }^{55}$ In the case of cells, the interplay between spontaneous order and change in form lies in a complex bio-mechanical and chemical process, in which-to put it in a nutshell-in a first step, the cell bio-mechanically 'feels' its position (form) in its environment, and thus also 'feels' the environment as such; then, this information is sent to the genome in the cell's nucleus, and finally, the genome sets off a gene cascade, in order to set off further changes on the desired path of morphogenesis. Put simply, then, morphogenic changes are set in motion, are then checked against the position aimed at in the system, and against the position relative to the system's environment, and, in a feedback loop, are checked against the changes aimed at, and then in accordance with this

\footnotetext{
${ }^{52}$ Kauffman, The origins of order (n 50 above) 219 et seq, and 255 et seq; see Amstutz, Evolutorisches Wirtschaftsrecht (n 43 above) 278 et seq, 286 et seq and 290 et seq; see also A Watson, The Evolution of Western Private Law (Baltimore, John Hopkins University Press, 2001) 264 et seq.

${ }^{53}$ Luhmann, Das Recht der Gesellschaft (n 26 above) 281; see also Amstutz, Evolutorisches Wirtschaftsrecht (n 43 above) 290 et seq, and Watson, The Evolution of Western Private Law (n 52 above) 264.

${ }^{54}$ LG Harrison, 'Physical chemistry of biological morphogenesis' (1981) 10 Chemical Society Reviews 491 at 491 and 502; DJ Depew and BH Weber, Darwinism Evolving: Systems Dynamics and the Genealogy of Natural Selection (Cambridge MA, MIT Press, 1997) 528 et seq, with further references.

55 Among many, see FW Cummings, 'Aspects of growth and form' (1994) 79 Physica D: Nonlinear

Phenomena 146-63; Spirov, 'Game of Morphogenesis' (n 48 above).
} 
result and the morphogenesis [p. 267] aimed at, and the new changes in turn are set off, etc. ${ }^{56}$ This morphogenic loop is, however, only one source of the change. Equally decisive are the aforementioned spontaneous order, and the rigid geometric constraints to which the system is subject, and along which it evolves. ${ }^{57}$

If this image of spontaneous order and morphogenesis is applied to the case of hybrid networks, it may be concluded that a system - in our case that of the CDB, mainly the economy, but also politics - will differentiate a particularly flexible sub-order if it has to respond to intensive and complex irritations from the environment. The system will do so by lowering its coherence, ie, bringing about a process towards a more complex form-while simultaneously maintaining its own autopoiesis. While the sub-order's specific rationality ensures a certain resistance to evolution (form), its dynamic elements will be sufficiently loosely linked to react to the irritations from the environment-but only so loosely as always to allow the sub-area's specific rationality to be maintained. The form of the hybrid network with its particularly loosely-linked elements is, then-as Teubner has shown-particularly appropriate whenever internal variations have to be formed out of contradictory or even paradoxical high-intensity irritations. ${ }^{58}$ In effect, the point for the system is, thus, to exploit the network in order to revamp the relationship between function, performance and reflection within the system in such a way that it can react as optimally as possible to intensive, complex and even contradictory demands from the environment without endangering its intrinsic rationality. ${ }^{59}$

\footnotetext{
${ }^{56}$ NK Bjorklund and R Gordon, 'Nuclear state splitting: a working model for the mechanochemical coupling of differentiation waves to master genes' (1993) 24 Russian Journal of Developmental Biology 79-95; similarly earlier Harrison, 'Physical chemistry of biological morphogenesis' (n 54 above) 502 et seq, and LG Harrison, 'Kinetic Theory of Living Pattern and Form and Its Possible Relationship to Evolution' in BH Weber, DJ Depew and JD Smith (eds), Entropy, Information, and Evolution: New Perspectives on Physical and Biological Evolution (Cambridge MA, MIT Press, 1988) 63 and 73, referring to SA Kauffman.

${ }^{57}$ FW Cummings, 'The Interaction of Surface Geometry with Morphogens' (2001) 212 Journal of Theoretical Biology 303-13.

${ }^{58}$ G Teubner, Recht als autopoietisches System (Frankfurt aM, Suhrkamp, 1989) 75; Amstutz, Evolutorisches Wirtschaftsrecht (n 43 above) 290 et seq.

${ }^{59}$ There would, of course, also be much to say about the CDB network in terms of social systems, organisation and interaction. I will, however, concentrate below on the level of co-evolution of social subsystems. On this distinction, see N Luhmann, 'Interaktion, Organisation, Gesellschaft' in Soziologische Aufklärung 2 (Opladen, Westdeutscher Verlag, 1975).
} 
This adaptation of the system now occurs in a morphogenic feedback loop along the system's intrinsic constraints: at the loci of the structural couplings, the system 'feels' its form and its position in the environment, and, from this information, the system takes on variations within the context of the sub-system's specific rationality, which are subjected to [p. 268] selection (change or non-change to the previous elements and structures). The modification brought about by the selection, as well as the rejection of modification, are in turn 'felt' for their position within the system and-again with the help of structural couplings-so is the position in the environment, which can now set off new variations and selections in a further loop.

The special thing about the form of the hybrid network is that it can simultaneously take up manifold structural couplings with various systems. This gives more importance to the morphogenic loop, in which the results of previous selections can be squared with the internal and external demands upon the system, and, if need be, corrections can be made, until, in the long run, a punctuated equilibrium between the system and its environment is reached. In this light, the morphogenic loop is the precondition for a system's being able to take on intensive demands from its surrounding systems while at the same time maintaining its own rationality, and to aim at a punctuated equilibrium with its surrounding systems.

I wish now to use the specific example of the $C D B$ network to show that, in this case, the economy responded to intensive and contradictory irritations with the form of the hybrid network, and thus differentiated a specific sub-order which created the conditions for the possibility of co-evolution for the economy with its surrounding systems through morphogenic loops. On the basis of the model of a poly-contextual society, ${ }^{60} \mathrm{I}$ shall further seek to draw normative conclusions from the observations derived from evolutionary theory.

\footnotetext{
${ }^{60}$ Among many, see G Teubner, 'Vertragswelten: Das Recht in der Fragmentierung von private governance regimes' (1998) 17 Rechtshistorisches Journal 234 at 234 et seq, and esp at 241 et seq; M Amstutz, 'Vertragskollisionen: Fragmente für eine Lehre von der Vertragsverbindung' in H Honsell, W Portmann, R Zäch and D Zobel (eds), Aktuelle Aspekte des Schuld- und Sachenrechts: Festschrift für Heinz Rey zum 60. Geburtstag (Zürich, Schulthess, 2003) 165 et seq, and, most recently, see Amstutz, Abegg and Karavas, Soziales Vertragsrecht (n 15 above).
} 
Here, however, there is a need to take account of intrinsically legal constraints in the form of the rigid compulsory connections of legal doctrine. The institutions of organisation and contract in law build upon long traditions, whereas the forms between organisation and contract and between the state and private organisation were banished with the emergence of the police state. ${ }^{61}$ Thus, there is no updated pool of elements that is able-without further ado - to be linked up with today's [p. 269] legal doctrine, from which suitable variations for the new types of phenomenon can be selected. Additionally, in today's post-modern poly-contextual society, pre-liberal solutions for a stratified society can be considered only with great caution. Thus, the locating of new phenomena, such as hybrid networks between government administration and private persons cannot be linked up with existing concepts, and the creation of a corresponding field of law ex nihilo is out of the question, even if only because of the internal constraints of legal doctrine. This legal doctrine watches too rigidly over the consistency of new norm variations with the existing norms. Accordingly, the new-style phenomena located between the old dichotomies of contract and organisation or of state and private organisation must be found a place in these existing dichotomies, although, of course, their 'reverse side' has to be taken account of within the relevant legal order.

\section{THE CDB IN THE LIGHT OF EVOLUTIONARY NETWORK THEORY}

\section{III.1 Development of Paradoxical Demands: Co-operation of Competitors}

The Texon scandal may definitely also be seen as one that was internal to politics. This is because Swiss policy, which profits from the banking business through taxes and levies,

\footnotetext{
${ }^{61}$ On this, see JHG von Justi, Grundsätze der Polizeiwissenschaft (Göttingen, 1782/1756), preface, and JHG von Justi, Die Grundfeste zu der Macht und Glückseeligkeit der Staaten, oder, Ausführliche Vorstellung der gesamten Policey-Wissenschaft (Königsberg, 1760) vol 2, § 554-5. Chiefly, since the sixteenth century, the aim was to bring the fragmented jurisdiction of church, landowners, etc, under state control as the sole kind of local government. The more this succeeded, the more the concepts of political power (as the capacity to secure obedience) and legal power came to coincide in sovereignty as supreme power. To date, the field is still marked by Hobbes' theory of the state: see Luhmann, Das Recht der Gesellschaft (n 26 above) 407 et seq.
} 
was afraid of falling further into disrepute and felt, accordingly, under pressure to act correctively against the banks. ${ }^{62}$ However, for manifold reasons, such as complexity and technicality, limited means and privatisation - in addition to the globalisation of both knowledge and resources - politics had failed to regulate the dynamic economic sector of the banks authoritatively through traditional legislation. ${ }^{63}$ Furthermore, the avoidance of political regulation that might have hampered 'normal banking business' was a primary [p. 270] objective of Swiss banks. ${ }^{64}$ As a result of further scandals and major political events, this aim could not fully be achieved. ${ }^{65}$ But the objective of not letting "normal banking business' be 'hampered', thus averting a politically-imposed straitjacket (and let it be it noted that the sub-area's specific rationality under the sign of extreme plasticity clearly shines through), is still, to this day, formulated with noteworthy clarity in the CDB:

This agreement lays down, with binding effect, valid rules of good conduct in bank management as a code of professional ethics. They should put in concrete terms certain points of due diligence governed by the Anti Money Laundering Act (Article 3 through 5 of the AMLA) and 'the diligence that can be reasonably expected under the circumstances' (Article 305ter of the Swiss Penal Code). Special due diligence rules for business relations and transactions involving higher risks are set forth in the Anti-MoneyLaundering Ordinance by the Swiss Federal Banking Commission.-This is not intended to impede normal banking business. ${ }^{66}$

How could this objective be achieved? To avoid an inconvenient straitjacket through political regulation, politics had to be irritated by the economy in such a way as to eliminate the preconditions for politics to take regulatory action. If, however,

\footnotetext{
${ }^{62}$ See NZZ 6 May 1977, p 17 and NZZ 5 May 1977, pp 25 and 29, especially, the Federal Council's statement on the Bank scandal; Jung, From Schweizerische Kreditanstalt to Credit Suisse Corp (n 5 above) 261.

${ }^{63}$ On these factors, very widely held responsible for the increasing co-operationism of governmental administration, see, among many, TP Müller, Verwaltungsverträge im Spannungsfeld von Recht, Politik und Wirtschaft: eine systemtheoretische Analyse von Verträgen zwischen dem Gemeinwesen und Privaten mit Hinweisen auf die rechtsdogmatischen Konsequenzen (Basel, Helbing \& Lichtenhahn, 1997)142 et seq; P Uebersax, 'Privatisierung der Verwaltung' (2001) 102 ZBL 393-422; P Zumbansen, 'Spiegelungen von "Staat und Gesellschaft": Governance-Erfahrungen in der Globalisierungsdebatte' in M Anderheiden, S Huster and S Kirste (eds), Globalisierung als Problem der Steuerungsfähigkeit des Rechts und der Gerechtigkeit, ARSP Beiheft 79 (Stuttgart, Steiner, 2001).

${ }^{64}$ See the leading article in the NZZ 7/8 May 1977 and the reports of the parliamentary debate in the NZZ 5 May 1977, pp 25 and 29; see, also, Mach, Schnyder, David and Lüpold, 'Transformations de l'autoregulation et (re)regulation publique en matiere de gouvernement d'entreprise en Suisse (19802002)' (n 19 above).

${ }^{65}$ See details at $\mathrm{n} 5$ above; also in Section I.2.

${ }^{66}$ Article 1(3) CDB 2003.
} 
individual economic actors had unilaterally and voluntarily taken political instructions as politico-ethical guidelines and had thus restricted their economic possibilities in the light of politics, then clearly these individual banks would have faced considerable competitive disadvantages in comparison with non-compliant competitors-without necessarily getting rid of the problem for politics. A unilateral adaptation by banks to the demands of politics was thus manifestly illusory because of the constraints immanent in the economic system. ${ }^{67}$

As we know, ordo-liberal theory (a German school of neo-liberalism) turned liberalism on its head by recognising that a market regime is not the consequence of, but a precondition for, the market mechanism. ${ }^{68}$ In [p. 271] the light of this ordo-liberal theory, it was up to the banks jointly to set up a market regime that simultaneously and equally restrained the economic possibilities of the biggest players in the banking sector and was, therefore, at least within the circle of important market participants, or the most part competitively neutral in its effects, ie, cartelised the new duties of care. ${ }^{69}$ Joint action to this end by the competitors would, however, have brought considerable dangers. By founding a formal organisation, the competitors would have come so close together as to call the fundamental premises of the market into question, whilst, at the same time, bringing the risk of corresponding reactions from politics and law. The banks thus found themselves facing the paradoxical requirement to co-operate with each other whilst, at the same time, maintaining competition.

The form of the network does not-as anti-trust law ${ }^{70}$ might suggest - resolve this paradox by [p. 272] suppressing one side of the organisation, but instead unfolds the

\footnotetext{
${ }^{67}$ On the problems of business ethics, see N Luhmann, Die Wirtschaft der Gesellschaft (Frankfurt aM, Suhrkamp, 1989) 84 et seq.

${ }^{68}$ See the excellent presentation of the circumstances in R Wiethölter, Rechtswissenschaft (Franfurt aM, Fischer, 1968); and fundamentally on this, F Böhm, Wettbewerb und Monopolkampf (Berlin, Heymann, 1933).

${ }^{69}$ On the interplay between the legislation framework set up by the state and self-regulation of the market, see F Böhm, 'Privatrechtsgesellschaft und Marktwirtschaft' (1966) 17 ORDO 75-151, and E-J

Mestmäcker, 'Die Wiederkehr der bürgerlichen Gesellschaft und ihres Rechts' (1991) 10

Rechtshistorisches Journal 177-92. On the cartellisation effect of social norms, see S Huf, 'Die sozialstaatliche Einbettung der Marktökonomie' (1999) 45 ZfS 221 at 227 et seq.

${ }^{70}$ The first anti-trust act to protect competition dates from 1985 (see official collection of Swiss law 1986 874).
} 
paradox by using both co-operation and competition. How does this look in the CDB case? In the CDB network, regulations were formulated in which the economy, to some extent, took the environmental demands into account - specifically, in the banking area, it restricted the possibilities of business action. However, since this restriction of economic rationality in bilateral arrangements was stabilised through contract law, as, from a certain threshold of collective market power onward, the result was the above-mentioned cartelisation. This means that the arrangement stabilised in the contracts became competitively neutral, since one market participant no longer competed with another by underbidding the established standard. The network, in structural coupling to the legal system through the various bilateral, but always identical and inter-related, contractual arrangements, thus obtained control over the opportunistic conduct of its participants in a specific sub-area of competition, while the network participants continued to compete with each other in the other areas. ${ }^{71}$

The economy was thus able to overcome the blockade which threatened the banking sector with paradoxical demands, through a network-type organisation which was flexible enough to unfold the paradox by introducing several levels. The networktype web of contracts was able, on the one hand, to secure the very co-operation that could meet the political demands, while, on the other hand, this co-operation-in the form of the conclusion of a contract between the individual bank and a neutral network centre-was so loose and so limited in content that not only was the form of competition maintained for the economic system, but this could correspondingly also be signalled to the other systems, especially the legal system. ${ }^{72}$ This simultaneously minimised the target area for political or legal interventions and thus averted excessive influence by legislative

\footnotetext{
${ }^{71}$ This was secured by an arbitration clause, which presupposed a private law contractual arrangement: see Article 14 CDB 1977.

72 The central function of the contract for networks is also stressed by J Sydow and A Windeler, 'Steuerung von und in Netzwerken - Perspektiven, Konzepte, vor allem aber offene Fragen' in J Sydow and A Windeler (eds), Steuerung von Netzwerken (Opladen, Westdeutscher Verlag, 2000) 14 et seq Here, however, the point is not so much the classical contract, nor a long-term continuing contract, but a mediumterm contract that gives the parties decisive freedom to adjust the contractual relationship to changing circumstances: OE Williamson, 'Comparative economic organisation: The analysis of discrete structural alternatives' in SM Lindenberg and H Schreuder (eds), Interdisciplinary Perspectives on Organization Studies (Oxford, Pergamon, 1991).
} 
policy; as the network was arranged, and, as this was also perceived by the Federal Court, it was meant to constitute only a loosely associated bundle of private contracts.

How, then, is this re-entry of organisation into contract to be classified legally? In the law of contract, it can be brought into the content of the contract (if need be, interpreted normatively) without problems. ${ }^{73}$ A sober glance at anti-trust law, however, raises doubts as to whether the $\mathrm{CDB}$ ought not to be brought under the Cartel Act. ${ }^{74} \mathrm{We}$ may regard the CDB as a strategy of the economy for organising the sub-area of banking in such a way that it can absorb complex and intensive irritations from the environment on the basis of its internal order (in SA Kauffman's sense) and respond to them flexibly (through morphogenic loops). ${ }^{75}$ Thus, it would, against the background of the model of a poly-contextual society, be downright fatal for the law to force the network into the traditional dichotomies of competition versus co-operation, or contract versus organisation. It would be fatal to describe it as an illicit competition agreement and thus suppress the organisation element, or else construe it as an organisation, which would fail to take the central role of the contract into account. Therefore, from this viewpoint, the so-called re-entry of the organisation into the form of the contract deserves protection - at least in so far as it allows the economy both to absorb [p. 273] irritations from the environment better, and correspondingly to orient its structure better to the demands of the surrounding systems. ${ }^{76}$

\footnotetext{
${ }^{73}$ See, for example, the forms of contract in favour of third parties (Art 112 OR). See, with further references, P Krauskopf, Der Vertrag zugunsten Dritter (Diss.) (Fribourg, University Press Fribourg, 2000).

${ }^{74}$ See also Zuflauf, 'Gläubigerschutz und Vertrauensschutz: Zur Sorgfaltspflicht der Bank im öffentlichen Recht der Schweiz' (n 7 above); see Art 5 f. $K G$ (Cartel Act).

${ }^{75}$ See Section II.

${ }^{76}$ In fact, the CDB, in which Switzerland's biggest banks were involved from the outset, clearly does eliminate competition in the area regulated: Zulauf, 'Gläubigerschutz und Vertrauensschutz: Zur Sorgfaltspflicht der Bank im öffentlichen Recht der Schweiz' (n 7 above) explicitly states this. By the political exceptional clause of Art 6(2) $K G$ (Cartel Act), however, the competition arrangements, which are designated in ordinances and public announcements and concern 'particular forms of co-operation in single economic sectors, especially agreements on the rational implementation of public-law measures to protect customers and investors in the financial services area', are justified. See the Swiss Federal Council's message on auditing in BB1 1994, 564, which refers explicitly to the banking sector. In Art 6(2) $K G$, the legislator acknowledges that co-operation arrangements may also support competition or be of public (ie, primarily political) interest, as specifically the legislative reference to consumer protection in the area of financial services shows. This niche of the anti-trust system was able to bring in the more recent recognition that while competition is certainly the fundamental premise of the market economy, it may very
} 
However, the network not only allows the economy to absorb intensive contradictory, or even paradoxical, demands, but it also has a socially integrative function. What this socially integrative function of the CDB network consists of, and what part the morphogenic loops mentioned play, I shall now proceed to explain.

\section{III.2 Compatibilisation of Contradictory Rationalities}

After the Texon scandal, the banking sector not only had to create a market regime while simultaneously maintaining competition, but was additionally confronted with a second contradictory demand. The banking sector had to come closer to politics while, at the same time, keeping it at arm's length: the CDB network was called into being primarily to cushion pressures from international and national politics and make them compatible with the banking sector. ${ }^{77}$ Correspondingly, connections with this political dimension were established from the outset, first by bringing in the National Bank as the network centre, and in the second phase of the $\mathrm{CDB}$, by integrating the Federal Banking Commission as the top supervisory body for the network. Nonetheless, it was always an [p. 274] intention of the CDB to keep the influence of politics as 'business-compatible' as possible, something clearly expressed in Article 1 of the CDB mentioned earlier. ${ }^{78}$

How, then, was the economy able to use the network to respond to the paradoxical requirement to include politics while, simultaneously keeping it at arm's length? I wish here to distinguish two dimensions: first, communication about the need for collectively binding-decisions, and second, the problem of legitimation.

\footnotetext{
well be compatible with that premiss for firms, for the most varied purposes and on specific points-ie, product-, project- or time-related - to change from competitors to co-operating partners: see H-J Bunte (ed), Kommentar zum deutschen und europäischen Kartellrecht (Neuwied, Luchterhand, 2004) § 1, fn 161; C Kirchner, 'Unternehmensorganisation und Vertragsnetz' in C Ott and H-B Schäfer (eds), Ökonomische Analyse des Unternehmensrechts : Beiträge zum 3. Travemünder Symposium zur ökonomischen Analyse des Rechts (Heidelberg, Physica Verlag, 1993); see also P Zurkinden, HR Trüeb and J Rutishauser, Das neue Kartellgesetz Handkommentar (Zürich, Schulthess, 2004), on Art 6 KG (Cartel Act).

${ }^{77}$ See above Section I.2.

${ }^{78}$ Note 66 above. T Strulik, 'Governance globalisierter Finanzmärkte: Policy-Netzwerke und Kontextsteuerung im Bankensystem' in J Sydow and A Windeler (eds), Steuerung von Netzwerken (Opladen, Westdeutscher Verlag, 2000) at 322, points out that something similar is true of the international level, too. However, he portrays an almost harmonious picture of the co-operation of the economy and politics in networks, something that cannot be asserted of the CDB case.
} 


\section{II.2.(a) Communication about the Need for Collectively-binding Decisions}

If the economy wishes to signal the need (or else non-need) for collectively bindingdecisions to the political sphere, this communication cannot occur just anyhow and anywhere. If we take the model of the polycontextural society seriously, then, because of the unbridgeable autonomy of the various systems and of the corresponding Babylonian confusion of tongues, there is no direct communication channel between the economy and politics through which this information could pass without further ado. And correspondingly, even in the network the various rationalities cannot 'find each other' in such a way that, à la Savigny, they would all be within some all-embracing world-spirit. ${ }^{79}$ From the viewpoint of systems theory and evolutionary theory, the economy is left with no alternative but to irritate politics at the locus of structural coupling by which the necessary variations are formed and selected ${ }^{80}$ Although the chances of success in bringing about the desired selections in a surrounding system through irritations have to be rated as poor, the $\mathrm{CDB}$ network did manage to install relatively effective morphogenic structures by simultaneously linking up to several structural couplings:

\section{(i) Organisation and Collective Actor as Structural Coupling}

Whereas the network appears to the law primarily as a bundle of contracts, because of the network effect, it does, at the same time, present itself to politics as an organisation, or more precisely, as a collective actor. This enables the relevant sub-area of the economy to appear to legislative policy as a point of identification at which politics obtains information about the other [p. 275] system, and, in particular, about the conditions for collectively-binding decisions, and communicates the possibility conditions for future collectively-binding decisions, in order to test the chances for achieving political programmes on the basis of reactions. The economy, for its part, reads this communication about planned collectively-binding decisions as a cost, and, in turn, uses the organisation to communicate the need or lack of need for collectively-binding

\footnotetext{
${ }^{79}$ FK Savigny, System des heutigen Römischen Rechts, Band 1-4 (Berlin, Veit, 1973/1840) vol I, 22 et seq. ${ }^{80}$ A Abegg, 'Evolutorische Rechtstheorie' in S Buckel, R Christensen and A Fischer-Lescano (eds), Neue Theorien des Rechts (Stuttgart, Lucius und Lucius, 2006).
} 
decisions to the political sphere. ${ }^{81}$ For the banking sector, this possibility of communicating to the political sphere a lack of need for legislative intervention about duties of due diligence is of central importance. This is because it is in this way that politics could, and, indeed, can be relatively quickly and reliably made aware of the efforts to reach a punctuated equilibrium with politics within the economy. In our case, politics, too, was pressing for a solution to the crisis (within politics) of Switzerland as a banking centre, and, from the viewpoint of the economy, the slowly grinding and (for the economy) incalculable mills of legislation should, if it all possible, not be set in motion at all. $^{82}$

\section{(ii) Contract as Structural Coupling}

While the necessary communication between the banking sector and legislative politics could not have been established through the structural coupling of the contract alone, the contractual incorporation of the National Bank, a political actor of great renown, as network centre, made it easier, especially at the beginning, after the influential Texon scandal, for the network to get a hearing from it. This is because, through the contract as structural coupling via which projects of various systems could, using law, be stabilised for a definite duration, the National Bank was able to bring the concerns of politics almost directly into the network. ${ }^{83}$ Alongside this specific 'release' of a narrow range of irritations, however, the irritations at the site of the structural coupling were, at the same time, limited and an important pre-condition for the compatibilisation of the systems created by it: the network participants gave up their autonomy in two respects, so as to enable co-operation in the network. Not only did the economic actors involved in the network abstain from any actions which, while bringing them competitive advantages on the market, put co-operation in the [p. 276] network into question, but also reduced their

\footnotetext{
${ }^{81}$ A Brodocz, 'Strukturelle Kopplung durch Verbände' (1996) 2 Soziale Systeme 361 at 367; G Teubner, 'Polykorporatismus: Der Staat als "Netzwerk" öffentlicher und privater Akteure' in H Brunkhorst and P Niesen (eds), Das Recht der Republik (Frankfurt aM, Suhrkamp, 1999) 349; N Luhmann, Die Politik der Gesellschaft (Frankfurt aM, Suhrkamp, 2002) 396 et seq.

${ }^{82} \mathrm{See}$, eg, the leading article in the NZZ 7/8 May 1977. See, also Section I.2 above.

${ }^{83}$ On the contract as structural coupling, see, among many, G Teubner, 'Ein Fall von struktureller Korruption? Die Familienbürgschaft in der Kollision unverträglicher Handlungslogiken (BVerfGE 89, 214 et seq)' (2000) 83 KritV 388-404; Teubner, 'Vertragswelten' (n 60 above); Amstutz, Abegg and Karavas, Soziales Vertragsrecht (n 15 above).
} 
autonomy in mutually shaping their business relations, while the government administration involved also restricted its own possibilities of acting in the banking sector by way of the hierarchical legislative process. ${ }^{84}$

This self-restraint of the systems involved presupposes their maintenance of their respective intrinsic rationalities. Thus, the example of the early $\mathrm{CDB}$ shows that the network could not be stabilised with a weakly legitimated public institution - in this case the National Bank, which while it did have the necessary reputation, lacked any suitable statutory basis. ${ }^{85}$ This is because if the network positions itself at the intersection of the economy and politics in order to influence the framework conditions of a market decisively, then it is dependent on the link to the power and legitimation resources of politics. We shall come back to this. ${ }^{86}$

The network thus constitutes an institutional strategy of society's mutually estranged sub-systems in order to have dealings with each other on condition that they maintain their own intrinsic rationalities, in search of a punctuated equilibrium. To this extent, the chameleonic network form has evolutionary importance in rendering contradictory rationalities compatible. ${ }^{87}$ The general picture is that the economy, using the structural couplings, 'feels' its own position in relation to the demands of politics, in order to set off, on the basis of this information, changes in the sub-area of the banking sector through the structural linkage of the contract, which will, in turn, be brought to the attention of politics through the structural coupling of organisation, and checked for success, etc.

These morphogenic processes not only have to be respected, but also normatively underpinned, from the legal viewpoint; but, here, neither a reconstruction of the network solely as a disconnected bundle of contracts nor solely as an organisation will suffice; just

\footnotetext{
${ }^{84}$ See Teubner, 'Polykorporatismus' (n 81 above) 363 with further references.

${ }^{85}$ This warning was already given by C Schmid, 'Die neue Vereinbarung über die Sorgfaltspflichten der Banken' (1983) 79 SJZ 69 at 72. Messner, 'Netzwerktheorien' (nn 42 and 52. For the question of legal statutory basis, see (n 22 above).

${ }^{86}$ Passim, Section III.2.

${ }^{87}$ Fundamentally on this, see Teubner, 'Das Recht hybrider Netzwerke' (n 45 above) 570; Teubner, 'Coincidentia Oppositorum: Hybrid Networks beyond Contract and Organisation' (ch 1), in this volume.
} 
as neither one from a purely economic nor from a purely political viewpoint will. Instead, the need is first to secure the re-entry of the organisation form into the content of the contracts in such a way that the process of squaring off between the systems of the economy and politics can take place at the site of the structural coupling of the organisation. And secondly, the various differing rationalities that come together in the network must be secured [p. 277] against one another. ${ }^{88}$ In summary, what is involved here is the institutional guaranteeing of the network in the light of its evolutionary function.

But this is only one side of the coin. The contractual form - as the Federal Court's decision $109 \mathrm{Ib} 149$ shows - also offers good protection against claims and interference by third parties: the network ought, by no means, to appear to the law as an organisation. This is why third parties can be directed to its individual nodes, which, in turn, appeal against the accusation of breach of the law to the super-ordinate political aspect of the network effect, ie, the market regime. But this opens up a legitimation problem for the network, which I shall now examine.

\section{II.2.(b) Legitimation}

\section{II.2.(b)(i) The Problem}

In the case of the $\mathrm{CDB}$, the banking sector could not find a solution to this crisis without any political involvement at all from the outset. Initially, the banks needed a neutral arbitration agency, both to overcome the competition and set co-operation in motion. ${ }^{89}$ Thereafter, the involvement of a political actor helped the network to obtain a better hearing from politics. But this was not all: in order to implement a market regime, economic rationality needed the political symbols of constraint and indisposability.

But what is actually meant by this? It is already inherent in the concept of a market regime that it should apply to a whole sub-area of the economy and consequently affect a multiplicity of market participants at various levels, imposing restrictions upon their economic possibilities, and that it should, in the last instance, also be imposed

\footnotetext{
${ }^{88}$ Thus, also, the interpretation by Messner, 'Netzwerktheorien' (n 42 above) 50 et seq and 57.

${ }^{89}$ In fact, the National Bank took on a leading role in the coming to terms with the Texon-scandal: see NZZ 27 April 1977, p 17 and 28 April 1977, p 13.
} 
coercively. If, however, law - associated with the political symbol of constraint - is used instrumentally, for instance, as in our case, to secure a particular market regime, then the question of the legitimation of this law arises. The Swiss Federal Court decision $109 \mathrm{Ib}$ 146 commented upon above shows these issues clearly. What was being debated in decision $109 \mathrm{Ib} 146$ was the interests of the Treuhänder-Verband and its members. They had undergone a considerable competitive disadvantage from the new CDB arrangement, and yet were unable to influence the $\mathrm{CDB}$ - which had primarily been set up by the banks - in any way. Moreover, the reactions to the case clearly showed that purely private-law legitimation-legitimising the legal stabilisation of bilateral differentials by the free will of the participants, and the exclusion of third-party interests by [p. 278] the mechanism of the self-regulating market-was too weak to establish a permanent stabilisation, for the CDB network amounted to more than just a bundle of contracts. ${ }^{90}$ Instead, the intended network effect, by combining overwhelming market power and incorporating politics, attained something which exceeded the sum of the individual contracts, namely, a comprehensive market regime - and did so in a key market of central political importance. Today, these issues are already signalled in law by the fact that the Cartel Act is inapplicable simply because of political exceptional clauses. ${ }^{91}$ The legitimation issues were accordingly not resolved by the traditional legitimation mechanisms of private law, but, in their stead, recourse had to be had to political legitimation mechanisms. ${ }^{92}$

To obtain legitimation, it has to be admitted, the economy cannot copy the sort of ramified participatory procedures that serve to produce legitimacy for the democratic rule of law without denying its own rationality, which relies on lowering transaction costs. ${ }^{93}$ In this respect, it is subject to the constraints intrinsic to its system. Accordingly, the economy must find another way of obtaining the political symbolism of constraint and, above all, of legitimation for its self-regulation.

\footnotetext{
${ }^{90}$ On legitimation, see R Brownsword, 'Network Contracts Revisited' (ch 2) in this volume.

${ }^{91}$ See $\mathrm{n} 76$ above.

92 On this distinction, see Weber, Wirtschaft und Gesellschaft (Tübingen, Mohr \& Siebeck, 1980/19211925) 123.

${ }^{93}$ On legitimation in democracy under rule of law, see Luhmann, Das Recht der Gesellschaft (n 26 above) 416 et seq.
} 
In the $\mathrm{CDB}$ case, this was initially done by bringing a political actor into the network by contract. While the law enabled the rationalities involved in the contract to clothe their project in the form of law and thus link to the rule-of-law legitimation mechanisms, the involvement of politics was meant to convey the democratic aspects of legitimation. ${ }^{94}$ However, the co-operationist solution with the National Bank as network centre proved incapable of stabilisation, as the critique of the Federal Court decision 109 Ib 146 from legal scholars shows: the National Bank already lacked a statutory basis for becoming involved in this area at all. Thus, despite its great political prestige, it could not adequately convey the democratic symbolism, thus creating the danger of the very political interventions that were to be averted. Correspondingly, structural changes were initiated in the network, in order to oppose this danger. The National Bank was replaced in the network by the politically better underpinned Federal Banking Commission.

[p. 279] But even with the legislative mandate that the Federal Banking Commission possesses, a co-operationist combination of the economy and politics by contract would have been hard to stabilise. This is because the contractual combination between politics and the economy even threatens to break up the existing legitimation mechanisms of the democratic state under rule of law: if government administration is to be able to have dealings with other areas of society in co-operationist fashion, it must have the corresponding freedom to negotiate the ends and the means of this selfsame cooperation. Here, the administration determines not just the way to the political goal, but increasingly also the goal itself, thus calling into question the administration's formal and material legality as (i) (central for the economy) the guarantor of the rule-of-law restraints on social happenings and (ii) (for society in general) the intermediary of democratic legitimation in the form of a developed participatory procedure. ${ }^{95}$ Correspondingly, in the CDB network, the contractual connections between politics and

\footnotetext{
94 This is also indicated by Müller, when he calls the involvement of the National Bank the 'official veneer' for the CDB: Müller, 'Zur Rechtsnatur der Vereinbarung über die Sorgfaltspflichten der Banken bei der Entgegennahme von Geldern und über die Handhabung des Bankgeheimnisses' (n 6 above) 350 et seq.

95 J Habermas, Faktizität und Geltung: Beiträge zur Diskurstheorie des Rechts und des demokratischen Rechtsstaats (Frankfurt aM, Suhrkamp, 1992) 519 et seq; E Schmidt-Assmann, 'Das Recht der Verwaltungsverträge zwischen gesetzlicher Bindung und administrativer Gestaltung' in W Drenseck (ed), Festschrift für Heinrich Wilhelm Kruse zum 70. Geburtstag (Cologne, O Schmidt, 2001).
} 
the economy were loosened. The political actor was replaced at the network centre by the banks' own trade organisation, while politics repositioned itself at the periphery of the network and took on the role of overall governmental supervision. ${ }^{96}$ In this way, the network arrangement was, on the one hand, brought closer to an unproblematical privatelaw code of professional ethics, and, on the other, subjected to a public-law political framework system. ${ }^{97}$ These structural adjustments to the network justified the criticisms of the legal scholars who had sought to resolve the legitimation problem by extending the political demands and suppressing the contradictory demands of conflicting spheres of action. $^{98}$

With the partial retreat into the traditional dichotomies of public and private spheres, the network partially managed, through its withdrawal [p. 280] into more traditional self-regulation, to lessen the danger of politicisation through direct legislative intervention or through a judicial classification as public law, which would inevitably have seen the politicised 'public interests' alienating the network from economic rationality. However, the $\mathrm{CDB}$ also lost a significant part of its capacity to adapt to the contradictory demands of conflicting rationalities: the economy's direct link to the symbiosis of law and politics to secure the symbol of legitimation through a contractual connection with politics was largely severed, and the possibility of morphogenesis was thus restricted. Admittedly, the morphogenic structures remained, in so far as the economy and politics could continue to perform exchanges (or, more precisely, to irritate each other) about the need for collective decisions at the locus of the structural coupling of organisation. And with the Federal Banking Commission, politics could continue to benefit from the banks' specific technical knowledge of how a functioning market regime

\footnotetext{
${ }^{96}$ For the relationship between the CDB-supervision and the Federal Banking Commission, see de Capitani, 'Die Aufsichtskommission VSB und das zehnte Gebot' (n 7 above), and Zuberbühler, 'Das Verhältnis zwischen der Bankenaufsicht, insbesondere der Überwachung der einwandfreien Geschäftstätigkeit, und der neuen Sorgfaltspflichtvereinbarung der Banken’ (n 7 above).

${ }^{97}$ Section I.2 above.

${ }^{98}$ See, especially, Müller, 'Zur Rechtsnatur der Vereinbarung über die Sorgfaltspflichten der Banken bei der Entgegennahme von Geldern und über die Handhabung des Bankgeheimnisses' (n 6 above) and Rhinow, 'Verfügung, Verwaltungsvertrag und privatrechtlicher Vertrag' (n 21 above); with a similar opinion, Marti, 'Selbstregulierung anstelle staatlicher Gesetzgebung?' (n 33 above) 576, fn 81; and for another, differentiated one, Schefer, 'Grundrechtliche Schutzpflichten und die Auslagerung staatlicher Aufgaben' (n 33 above) 1139 et seq.
} 
is to be constituted, and, at the same time, let its demands flow into the network - albeit no longer in the existing differentiated co-operationist fashion, but only in the sense of an ordre public..$^{99}$ Politics thus lost influence over the details of the arrangement, and the economy now had no way of pushing the morphogenesis far enough for the political demands to be able to flow into the $\mathrm{CDB}$ directly via the structural coupling of the contract. Thus, today's numerous legal provisions in this connection are also pointers to the failures of the $C D B$ as an experimental programme, at least, in its original radicality. ${ }^{100}$ And even if a sizeable core of self-regulation has been left, we nonetheless have to state that today's self-regulation-as the Federal Court decision 125 IV 139 shows - cannot lead much further than a traditional code of professional ethics. ${ }^{101}$

From the viewpoint of an evolutionary theory taking the model of a polycontextural society as its basis, this development of the CDB is regrettable. This is because the original CDB network with its morphogenic structures had proved to be a promising strategy for opening up contradictory, and even paradoxical, demands at the intersection of conflicting social systems. Thus an important contribution to the coevolution and integration of mutually estranged social systems was [p. 281] performedwhile simultaneously maintaining each of their own intrinsic rationalities. ${ }^{102}$ This does not mean that one should forget the difficulties that the CDB network raised for politics. Certainly, in my view, the withdrawal into the traditional dichotomy of private and public came far too early. This is because there definitely are possibilities for reconciling a network structure, especially one based on the structural coupling of the contract for the integration of the mutually estranged systems, with the need for legitimation. I shall briefly outline these approaches to solutions.

\section{II.2.(b)(ii) Rule-of-Law Legitimation Mechanisms}

\footnotetext{
${ }^{99}$ For a description of reflexive regulation of the banking sector, see Strulik, 'Governance globalisierter Finanzmärkte' (n 78 above) 308 et seq.

${ }^{100}$ See, only, the now copious regulations in the Federal Act of 10 October 1997 to combat moneylaundering in the financial sector (Money-laundering Act) and the corresponding EBK order of 18 December 2002 on the prevention of money-laundering (EBK money-laundering order).

${ }^{101}$ See n 32 above.

${ }^{102}$ See Messner, 'Netzwerktheorien' (n 42 above) 58 et seq.
} 
When it comes to rule-of-law legitimation mechanisms, very basically and in the framework of the traditional application of fundamental rights, the effect of political communication on the economic side of the network can be tested against the fundamental rights:

(A) Freedom of the Private Person and Freedom of Thought

To the extent that the administration grants private persons the possibility, through their entry into a co-operative relationship directly with the administration, of preventing a command-type procedure being commenced, the freedom of the private person is not a pre-requisite. It is only once the private person is faced with the option between 'contract or command' that the decision in favour of freedom - pre-formed by the administrationcan be taken, in the light of the conduct demanded by it. The freedom traditionally presupposed in private law (as freedom to do something or not) is here conferred by the administration. Åkerstrøm Andersen has persuasively pointed out that before this conferred freedom as a premise, all that remains is bare 'freedom of thought' (Gewissensfreiheit). This freedom of thought constitutes the very residue of the traditionally presupposed freedom without preconditions that is due to human beings by virtue of their being human. ${ }^{103}$ The freedom conferred by the administration is thus far removed from the Kantian freedom, which has no prior cause, which is, transcendentally, a value in itself, and, as such, is, in principle, not dependent on sensuous or social needs, either. ${ }^{104}$ Here, the legitimating function of private law's delegation of self-organisation is almost completely absent, so that the co-operationist relationship between private persons and government administration is to be allocated to public law and its legitimation mechanisms, which are [p. 282] traditionally concerned with securing society's areas of freedom against the state, as well as with the legitimation of the

\footnotetext{
${ }^{103} \mathrm{~N}$ Åkerstrøm Andersen, 'The Contractualisation of the Citizen — on the transformation of obligation into freedom' (2004) 10 Soziale Systeme 273-91.

${ }^{104}$ I Kant, Kritik der reinen Vernunft (Hamburg, Felix Meiner, 1993/1787) 561 et seq; I Kant, Kritik der praktischen Vernunft (Hamburg, Felix Meiner, 1993/1788) 60 et seq; I Kant, 'Metaphysische Anfangsgründe der Rechtslehre' in Rechtslehre: Schriften zur Rechtsphilosophie (Berlin, Akademie Verlag, 1988/1797) 27 et seq.
} 
interventions that restrict freedom through the concept of the democratic rule of law. ${ }^{105} \mathrm{In}$ the case of the $\mathrm{CDB}$, the prospect of market regulation by legislative policy was not so immediate that the banks' freedom in the decision of whether and how to build selfregulation would have to be regarded as mediated by the state. Instead, the proactive conduct of the banks in the course of the evolution of the CDB shows that the decisive thrusts towards self-regulation always came from the private side. ${ }^{106}$

- Even if a case of self-regulation is - particularly on the criterion of freedom of decision-assigned to private law, we must first ask whether the governmental pressure for self-regulation or the pressure to co-operate infringes fundamental rights. Since free assent is constitutive for private self-regulation, a self-regulation imposed by governmental administrative units potentially constitutes an infringement of fundamental rights, which correspondingly has to be justified. Here we must also bear in mind the gradual evolution of the selfsame cooperation and self-regulations which may very well start within the framework of the fundamental rights, but which may later cross the threshold to infringe fundamental rights. Or, in other words, a gradual increase in duties of cooperation and self-regulation cannot justify an infringement of fundamental rights without further ado. ${ }^{107}$ For instance, the Federal Banking Commission ban on a CDB form upon which trustees could declare that the economic beneficiary, while known, would not be disclosed should correspondingly have been checked for compliance with fundamental rights. ${ }^{108}$

- It should then be a principle that politics is not to be freed of its ensuring liability ${ }^{109,}$ whenever it is involved in a regulation or influences it. Accordingly, in a mixed hybrid network, the political [p. 283] communications of the public-law network nodes must be challengeable as a decision, so that higher priority ought also to be attributed to the justification of the administrative decision. ${ }^{110}$ Clearly, this does not mean that every corresponding court decision would have direct repercussions on the network and on the private-law contracts: in so far as the

\footnotetext{
105 See, also, the neo-liberal position of W Zöllner, 'Regelungsspielräume im Schuldvertragsrecht' (1996) 196 Archiv für die civilistische Praxis 1 at 26 et seq and 35 et seq.

${ }^{106}$ Müller 'Zur Rechtsnatur der Vereinbarung über die Sorgfaltspflichten der Banken bei der Entgegennahme von Geldern und über die Handhabung des Bankgeheimnisses' (n 6 above) 350 et seq, argues in the opposite direction, but then calls the National Bank's involvement the 'official veneer' for the CDB.

${ }^{107}$ Di Fabio, 'Verwaltung und Verwaltungsrecht zwischen gesellschaftlicher Selbstregulierung und staatlicher Steuerung' (n 20 above) 256 et seq.

${ }^{108}$ See $n 24$ above.

${ }^{109}$ The concept of the ensuring state emphasises on a continuing state responsibility for the common good and rejects the idea that changes in statehood reduce state responsibility. See, eg, G F Schuppert, 'Der Gewährleistungsstaat_modisches Label oder Leitbild sich wandelnder Staatlichkeit?' in Schuppert (ed), Der Gewährleistungsstaat - ein Leitbild auf dem Prüfstand (Baden-Baden, Nomos, 2005) 11-52. See also Art 16, 86 Abs 2 of the treaty establishing the European Community, OJ C 325, 24 December 2002.

${ }^{110}$ N Luhmann, Legitimation durch Verfahren (Frankfurt aM, Suhrkamp, 1983/1969) 215 et seq.
} 
network is to be described as a bundle of private contracts, any infringement of the private-law rationality which, in principle, stabilises the bipolarity of the contracting parties and excludes third-party interests would require special justification. ${ }^{11}$ However, alongside the possibility of demanding damages from the political actors, an appropriate judgment ought also to impose upon political actors a duty to act upon the network. ${ }^{112}$

As an extension of this sort of mono-causal application of the fundamental rights against politics, the law has to call on the systems involved for a new way of applying them: a polycontextural application of the fundamental rights. This is because if politics can no longer be trusted with, nor be expected to handle, the constitutional shaping of the total polycontextural society, then the consequence is that each social sub-system has to be called on for a corresponding self-restraint, with — as its object - the legal liberation and, at the same time, the curbing of the system's specific rationality vis-à-vis internal spontaneous order and vis-à-vis other social sectors. ${ }^{113}$ This demand may be placed on the CDB network in various ways. In particular, the Federal Banking Commission, as the regulatory body, ought to call for this self-restraint when granting authorisation to the $\mathrm{CDB}$ in connection with the general clause of the Banking Act, which prescribes the ensuring of proper business conduct. And the courts should call for this sort of selfrestraint of economic rationality when - as in the Federal Court decision 109 Ib 146dealing with relevant cases. This sort of substantive self-restraint by the economy is often discussed under the heading of democratic legitimation mechanisms. I should like-again sketchily - to show how democratic legitimation mechanisms might be recast for these issues.

[p. 284]

\section{II.2.(b)(iii) Democratic Legitimation Mechanisms}

According to such authors as Habermas or Grimm, new types of administrative conduct, detached from the traditional structures of the democratic rule of law, can secure

\footnotetext{
${ }^{111}$ In detail, see P Gauch, 'Zuschlag und Verfügung_Ein Beitrag zum öffentlichen Vergaberecht' in Mensch und Staat, Festgabe für Thomas Fleiner (Freiburg iUe, édition universitaires, 2003).

${ }^{112}$ See also di Fabio, 'Verwaltung und Verwaltungsrecht zwischen gesellschaftlicher Selbstregulierung und staatlicher Steuerung' (n 20 above) 270 et seq.

${ }^{113}$ G Teubner, 'Globale Zivilverfassungen: Alternativen zur staatszentrierten Verfassungstheorie' (2003)

63 Zeitschrift für ausländisches öffentliches Recht und Völkerrecht 1-28; Messner, 'Netzwerktheorien’ (n 42 above).
} 
legitimation, above all, by supplementing recourse to normative grounds by a process of internal democratisation. This so-called internal democratisation can, according to areawith the exception of the legal protection to be adapted to the new forms-result from participation in administration, ie institutionalisation of ombudsforms within the administration, court-like procedures, hearings and publications, involvement in decisions of those affected or their representatives, etc. ${ }^{114}$ As with the concept of the social state, the point is for the individuals, or the addressees of the administrative action, to be put into a position to able to cultivate and protect their interests and bring them to bear on decision-making processes.

From the viewpoint of an evolutionary theory based upon systems theory, caution is, of course, in order here, since the polycontextural aspects of today's society, ie, the differentiation of society into various sub-systems, each functioning on a different intrinsic logic, have to be taken as the basis for the model of today's society, as achievements of modernity. Whether society's differentiation already contains - as in Teubner-a normative principle, ${ }^{115}$ or whether the observer has to take this differentiation as the basis for his model of society if he is to secure an adequate picture which he can orient himself by, need not be gone into here. This is because acknowledging the polycontextural society as a society of law can already point at the dangers, such as those described under the heading of Teubner's regulatory trilemma, which threaten if Habermas's proposals are implemented. ${ }^{116}$ Thus, in the light of evolutionary theory, we must be warned against any too direct interference with the complex, evolutionarily-grown structures of other sub-systems. ${ }^{117}$ The point must instead be-from the viewpoint of evolutionary theory-to support the system's internal

\footnotetext{
${ }^{114}$ Habermas, Faktizität und Geltung (n 95 above) 527 et seq; similarly, D Grimm, Die Zukunft der Verfassung (Frankfurt aM, Suhrkamp, 1991) 414.

115 Teubner, 'Ein Fall von struktureller Korruption?' (n 83 above); here di Fabio agrees with Teubner: di Fabio, 'Verwaltung und Verwaltungsrecht zwischen gesellschaftlicher Selbstregulierung und staatlicher Steuerung' (n 20 above) 262.

${ }^{116}$ G Teubner, 'Das regulatorische Trilemma: Zur Diskussion um post-instrumentale Rechtsmodelle' (1984) 13 Quaderni Fiorentini per la Storia del Pensiero Giuridico Moderno 109-49.

${ }^{117}$ In this sense, Schneider also warns against over-direct politicization of policy networks. Instead, he calls for a strengthening of the traditional democratic legislative processes: V Schneider, 'Möglichkeiten und Grenzen der Demokratisierung von Netzwerken in der Politik' in J Sydow and A Windeler (eds), Steuerung von Netzwerken (Opladen, Westdeutscher Verlag, 2000) 342 et seq.
} 
reorientation of function, performance and reflection through law, in such a way that the system [p. 285] can react optimally to intensive, complex and even contradictory environmental demands without endangering its own rationality. ${ }^{118}$ We shall come back to this.

However, we certainly should follow Habermas in his finding that numerous forms of co-operation between the state and private persons, as in our case of the early CDB network, cannot meet the demands of politics for legitimate regulation. Although the economy does link up with politics, it still either fails to achieve, within the concrete co-operation, the re-entry of the political sphere, or succeeds only insufficiently. Today, too, the continual demands from many legal scholars for a more strongly reinforced return of the network into public law indicate that the CDB still lacks legitimation, so that the banking sector has not yet met the political demands with regard to a punctuated equilibrium. How, then, can these demands of politics on the economy be supported by a polycontextural application of the fundamental rights?

\section{II.2.(b)(iv) Evolutionary-Procedural Legitimation Mechanisms}

The statements so far have identified the morphogenic structures ${ }^{119}$ of co-operationist and, in particular, network-type arrangements as an evolutionary strategy for adapting to the polycontextural society. This sort of morphogenic structure, supported by law, thus makes it easier for the various social systems to enter into dealings with each other, whereby the rationalities rebounding from each other within these structures have to be secured against each other by reconfigured fundamental rights.

The difficult constitutional question now is how the different systems can be brought - by law - to take into account the differentiation of their surrounding systems and their most important demands, in order to obtain a punctuated equilibrium. To apply this to the $\mathrm{CDB}$ case, how, on the one hand, can politics be induced, despite a political programme that has to be implemented and despite continuing ensuring liability, to

\footnotetext{
${ }^{118}$ On the triad of function, performance and reflection, see Luhmann (n 59 above).

${ }^{119}$ What is meant are particularly the feedback loops between the structural couplings and the selection within the system that repositions it within its environment: Section II above.
} 
respect economic freedom even within self-regulation (as the re-entry of the economy into politics)? And how, on the other hand, can the economy be induced to enter into the political demands for a legitimate CDB network (as re-entry of politics into the rationality of the economy) - especially if legislative interventions by politics are to be avoided on grounds of the legislator's being overburdened for the specific object, [p. 286] while, at the same time, the law in a polycontextural society has neither the knowledge nor the possibility of implanting specific, effective regulations into the economy? ${ }^{120}$

We can be helped over this uncertainty as to the right law by a procedural approach, as described by Wiethölter. He-much as Habermas has done-calls for the continual renewal of the integration of the society of law through the involvement of society in the production and justification of law, thus simultaneously creating a new type of legitimation. $^{121}$

In a procedural method, the courts, in particular, need to have more dealings than before with the differentiated polycontextural society. The job of finding sociallyadequate norms must no longer be delegated solely through private autonomy to the economy and through legislation to politics. In the difficult task of finding the legal needs of the polycontextural society, the courts are, of course, supported by the law's neighbouring sciences: law is structurally coupled with these (for example, legal sociology, legal philosophy, legal history, legal psychology, etc), first, via legal theory as the reflective mechanism of law, and secondly, in a narrowly limited normative fashion, through (mainly politically) inserted general clauses as well as norm references. The systems in conflict, such as the economy, the family or politics, are, however, just as far from science — be it economic, family or political science — as from the law.

If, then, as stated above, the need is to promote possibilities for the mutuallyestranged sub-systems of society to observe each other and respond to the various

\footnotetext{
${ }^{120}$ This is sometimes forgotten when the by now familiar concepts of a procedural or reflexive law are being talked about: see, eg, Strulik, 'Governance globalisierter Finanzmärkte: Policy-Netzwerke und Kontextsteuerung im Bankensystem' (n 78 above) 322 et seq, with an interesting perspective on the reflexive regulation of the international banking sector.

${ }^{121}$ Fundamentally, R Wiethölter, 'Materialization and Proceduralization in Modern Law' in G Teubner (ed), Dilemmas of Law in the Welfare State (Berlin, de Gruyter, 1982).
} 
demands of the surrounding systems, then attention must be directed not just to the structural couplings - which, as we have seen, enable systems to perceive themselves as the environment for the other systems in each case - but also to the structures on the basis of which systems respond to demands from their environment while taking account of their own intrinsic rationality. If these morphogenic structures are so threatened by one system that other systems can no longer adapt their operations and structures to the changing environment, the law should protect them. This could be done by, for example, a judicially-established obligation to contract. In particular, such a obligation to contract could be applied in cases like the Federal Court decision 109 Ib 146, when the political legitimation demands on a market regime established by the economy are not covered because of structural shortcomings. This, however, calls for some further explanation, as follows.

[p. 287] From the viewpoint of legal doctrine, decisions intended to promote a balancing of the relationship between function, performance and reflection within the system - in the CDB case to demand re-entry of the political demands into economic rationality-can be located in so-called niches ${ }^{122}$ : First, possible niches in which variations with contents capable of compatibilisation may be formed should be sought in the legal sub-system coupled with the observed rationality, in our case, law of contract. For the most part, such niches can be found in the form of reservation norms, which act as signal norms pointing to the issues in conflict. Such conflict norms are, as a rule, couched openly, in order to be able to grasp the evolutionary dimension of the coexistence of systems. Traditionally, in Swiss law of contract, the general clauses on public morals (Article $19 \mathrm{f} O R$, Article $27 \mathrm{f} C C$ ), good faith (Article $2 C C$ ) and the application of the law (Article $1 C C$ ) take on this role. ${ }^{123}$ Corresponding niches, through which the $\mathrm{CDB}$ network could be brought to render political demands compatible with

\footnotetext{
122 This model was developed for economic law: Amstutz, Evolutorisches Wirtschaftsrecht (n 43 above) 326 et seq.

${ }^{123}$ Swiss Civil Code $C C$ (SR 210); Swiss Code of Obligations $C O$ (SR 220). See, most recently, the methodological observations of P Gauch, 'Der Schätzer und die Dritten' in Norm und Wirkung: Festschrift für Wolfgang Wiegand zum 65. Geburtstag (Bern, Stämpfli, 2005).
} 
the rationality of the economic sub-system are, however, also present in anti-trust law. ${ }^{124}$ If the niche and the conflict norm have been set up, the need is then to identify the specific legal sub-rationality that produces consistency within the sub-systems. Only in this way can the reason for the conflict, on the one hand, and the external form of the evolutionary capacity, on the other, be recognised. This specific legal sub-rationality is to be gathered from the relevant precedents (empirically), because it is not already laid down fixedly from the outset, but is constructed through the applicable cases. ${ }^{125}$

Such a decision ought not only to protect the morphogenic structure in the case before judgment, but, simply because of its coarse structure, should also set off a complex process of 'social' law-making in an interplay of law, scholarship and the systems involved in the conflict. These systems are led by the judicial considerations to generate new variations, which are, in turn, checked by legal scholars for doctrinal consistency, and then, if need be, are presented to the courts for selection, [p. 288] perhaps sent back again, etc, - until a selection capable of stabilisation has been found. ${ }^{126}$ In short, the point is to refer the conflict back to the systems involved-with, of course, an indication of the solution to be sought.

In the $109 \mathrm{Ib} 146$ case, the problem was essentially that the legitimation for the market regime produced ought to have been brought about by politics and the law through the structural coupling of the contract. The specific shape of the CDB at the locus of the structural coupling of the contract suffered from the fact that no contractual partner adequately legitimated by political mechanisms was included in the network, so that the two systems of the economy and politics were brought together in a structurally unsatisfactory fashion. Accordingly, the network nodes ought to have been forced into contracting with the third parties concerned, until the network had linked its market

\footnotetext{
${ }^{124}$ By Art $7 K G$, abuse of a position of market domination is impermissible. Clearly, the TreuhänderVerband as consumer of the service could probably not have based its claim on antitrust law, since by Art $12 \mathrm{KG}$ claims arise under anti-trust law only for those who are 'hampered in the initiation or exercise of competition by an impermissible restraint of trade'; see also J Ensthaler and D Gesmann-Nuissl, 'Virtuelle Unternehmen in der Praxis - eine Herausforderung für das Zivil-, Gesellschafts- und Kartellrecht' (2000) 55 Betriebs-Berater 2265 at 2270.

${ }^{125}$ On all this: Amstutz, Evolutorisches Wirtschaftsrecht (n 43 above) 326 et seq; Abegg, 'Evolutorische Rechtstheorie' (n 80 above).

${ }^{126}$ See Amstutz, Abegg and Karavas, Soziales Vertragsrecht (n 15 above).
} 
regime with a sufficiently legitimated political body or established some other adequate source of legitimation, which would subsequently have led to a situation-specific re-entry of the political legitimation demands into the CDB's economic rationality and thus to a step in the direction of a punctuated equilibrium. This is because normative protection of the structural coupling of the economy and (legislative) politics also guarantees the possibility of co-evolution of the systems, allowing both of them to irritate each other with their respective demands. In the case of decision $109 \mathrm{Ib} \mathrm{146,} \mathrm{the} \mathrm{banks} \mathrm{involved} \mathrm{in}$ the network would then have been obliged to treat the members of the TreuhänderVerband on an equal footing with the privileged lawyers and members of the Chamber of Trustees and Auditors ('Treuhand- und Revisionskammer') in relation to the disclosure duty. ${ }^{127}$ Thus, a simple 'not that way' and relatively vague demands on the legal doctrine in the light of the above-stated normative demand ought to initiate a process wherebyutilising evolutionary structures in a procedural way-empirically underpinned solutions are sought. These solutions need to obey the strict normative requirements of the law, and, at the same time, have to respect and follow the selfsame rationalities that brought the conflict before the law.

Finally, it should be pointed out that, through this procedural approach, the various systems involved in the conflict are squared off with each other, along with the law, in evolutionary fashion at the locus of structural couplings, and, thus, a co-evolution of the systems is ensured, which reciprocally promotes the differentiation of the conflicting systems - in a direction towards constitutionalising the respective systems in relation to the systems in their environment, making them [p. 289] compatible. ${ }^{128}$ This procedural extension of law, set in motion by court decisions, is appropriate to new types of problems that arise in today's polycontextural society; it finds its normativity in formal respects by utilising the structural couplings of law and other social systems, and it moves in strikingly parallel fashion to the law's stated function of protecting the morphogenic structures between the systems involved, so that the systems, in our case,

\footnotetext{
${ }^{127}$ See $n 4$ above.

${ }^{128}$ Similarly, R Wiethölter, 'Recht-Fertigungen eines Gesellschafts-Rechts' in C Joerges and G Teubner (eds), Rechtsverfassungsrecht: Recht-Fertigung zwischen Privatrechtsdogmatik und Gesellschaftstheorie (Baden-Baden, Nomos, 2003).
} 
politics and the economy, can observe each other and guarantee each other in their differentiation. Or, to put it another way, the substantive normative demand for protection for morphogenic structures and structural couplings between the conflicting social subsystems, in order to guarantee the capacity for evolution (or as Wiethölter puts it: developmental dynamics), can be secured in the form of the procedural and evolutionary method of adjudication described, at the sites of the structural couplings between the law and the various social sub-systems. ${ }^{129}$ In this sense, the law-as called for by democratic legitimation theories - both involves the society of law in finding the law, and protects the differentiated society - as with rule-of-law legitimation theories - while at the same time preserving the central rule-of-law function of the courts.

${ }^{129}$ See also Wiethölter, 'Recht-Fertigungen eines Gesellschafts-Rechts' (n 128 above). 